\title{
Research Paper \\ The Role of the Developmental Environment (Home, Kindergarten, and Nursery) on the Intelligence Quotient and Social Skills of Children
}

\author{
Liela Mohammadi ${ }^{1}$, Parisa Hejazi Deanan*2, Parvaneh Shamsipour Dehkordi ${ }^{2}$ \\ 1. M.A. of Motor Behavior, Faculty of Sports Sciences, Alzahra University, Tehran, Iran \\ 2. Assistant Professor, Department of Motor Behavior, Faculty of Sports Sciences, Alzahra University, Tehran, Iran
}

Citation: Mohammadi L, Hejazi Deanan P, Shamsipour Dehkordi P. The role of the developmental environment (home, kindergarten, and nursery) on the intelligence quotient and social skills of children. Quarterly Journal of Child Mental Health. 2019; 6(3): $126-137$.

http://dx.doi.org/10.29252/jcmh.6.3.12

\begin{tabular}{ll} 
A R T I C L E I N F O & A B S T R A C T \\
\cline { 2 - 2 } $\begin{array}{l}\text { Keywords: } \\
\text { Environment, } \\
\text { child, } \\
\text { intelligence quotient, } \\
\text { social skills }\end{array}$ & $\begin{array}{l}\text { Background and Purpose: Research evidence suggests that the environment is an important factor } \\
\text { in child development; in such a way that enrichment of the environment can help to child growth. In } \\
\text { this regard, the present study was conducted to determine the role of environment on the intelligence } \\
\text { quotient and social skills of 4-6 year-old children in Tehran. } \\
\text { Method: This study was a descriptive and causal-comparative research. The study population } \\
\text { included all the 4-6 year-old children in Tehran in 2016-2017, who were living in the homes, } \\
\text { kindergartens, and nurseries. The research sample was consisted of 90 children (30 children in each } \\
\text { environment) that were selected by convenience sampling, based on inclusion criteria. Data were } \\
\text { collected using demographic questionnaire, social skills questionnaire (Matson, 1976), and child } \\
\text { intelligence quotient software (Rayon, 1947). One way ANOVA and Tukey's post hoc test were used } \\
\text { to analyze the data. } \\
\text { Results: The findings showed that the environment had a significant effect on the intelligence } \\
\text { quotient and social skills of children aged 4-6 years in Tehran city (p <0.05). Tukey's post hoc test } \\
\text { showed that there were significant differences in the intelligence quotient of children living in home } \\
\text { and those living in nursery, children living in home and those living in kindergarten, and children } \\
\text { living in kindergarten and those living in nursery (p=0.001). Also, significant difference was found } \\
\text { in the social skills of children living in home and those living in nursery (p=005) as well as between } \\
\text { children living in kindergarten and those living in nursery (p=0.001). But, no significant difference } \\
\text { was found between the children living in home and those in kindergarten (p=0.19). } \\
\text { Conclusion: The finding suggests that the kindergarten experience, which provides children with } \\
\text { more opportunities for learning and development in terms of educational materials and social } \\
\text { communication, is more appropriate for the child. }\end{array}$ \\
$\begin{array}{l}\text { Received: 28 Apr 2018 } \\
\text { Accepted: 14 Sep 2018 }\end{array}$ \\
\begin{tabular}{l} 
Available: 9 Nov 2019 \\
\hline
\end{tabular}
\end{tabular}

\footnotetext{
* Corresponding author: Parisa Hejazi Deanan, Assistant Professor, Department of Motor Behavior, Faculty of Sports Sciences, Alzahra University, Tehran, Iran.

E-mail addresses: Parisahejazi@alzahra.ac.ir
}

2476-5740/ (C) 2019 The Authors. This is an open access article under the CC BY-NC-ND license (https://creativecommons.org/licenses/by-nc-nd/3.0/). 


\section{نقش محيط تحولى كود كى (خانه، مهل، و شيرخواركاه) بر بهره هوشى و مهارتهاى اجتماعى كود كان

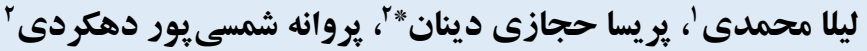

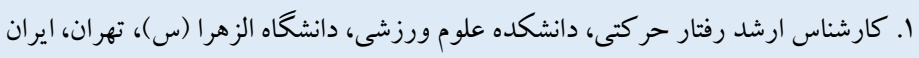

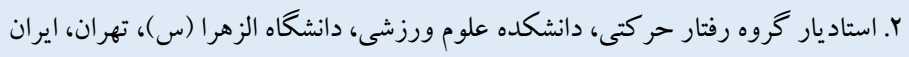

زمينه و هدف: شـواهد ئزوهـى حاكى از اين است كه محيط عامل مهمى در بهبود تحول كود كان است و با غنىسازى محيط مىتوان

جكيده

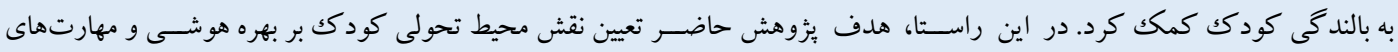

$$
\text { اجتماعى كود كان 4-9 سال شهر تهران بود. }
$$

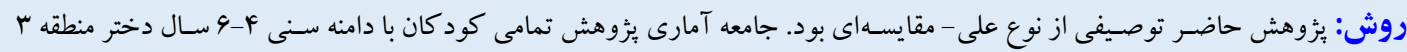

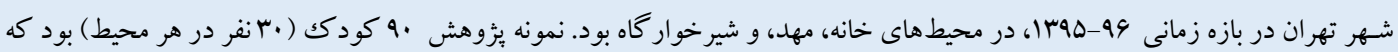

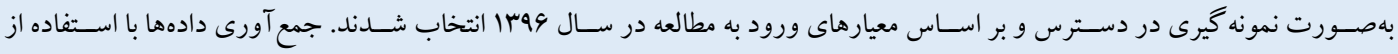

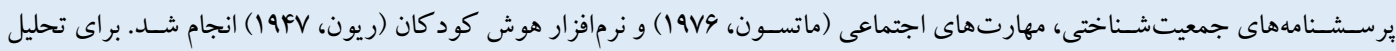
دادهها از روشهاى آمارى تحليل واريانس يككراهه و آزمون تعقيبى توكى استفاده شد. يافتها: نتايج تحليل واريانس يككراهه نشـان داد محيط فراهمسـاز بر بهره هوشى و مهارتهاى اجتماعى كود كان F-9 سـال تأثير داشت

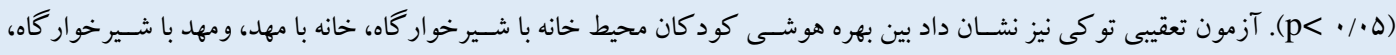

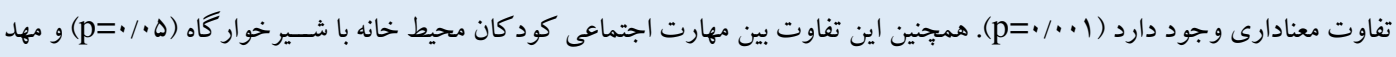

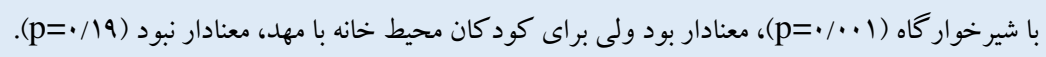
نتيجــه كيرى: بنـا بر يـافتهاى بثروهش حاضــر، بهره هوشـى و مهارت اجتماعى كود كان مهد بالاتر از كود كان سـاكن در محيطهاى

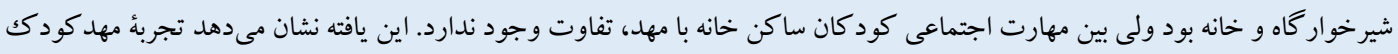

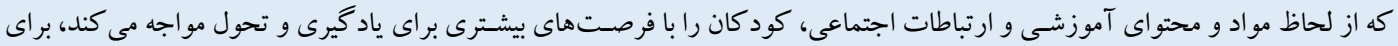
كودك مناسبتر است.
مشخصات مقاله

كليدوازهها: محيط تحولى كودك، بهره هوشى، مهارت اجتماعى

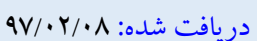
يذيرفته شده: منتشر شده: \$1/

* نويسنده مسئول: يريسا حجازى دينان، استاديار گروه رفتار حر كتى، دانشكده علوم ورزشى، دانشگاه الزهرا (س)، تهران، ايران.

رايانامه: Parisahejazi@alzahra.ac.ir

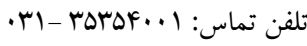


توسط ويو و همكاران در رابطه ارتباط بين مهارتهاى اجتماعى و روابط

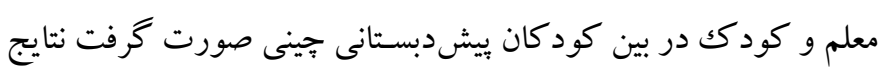

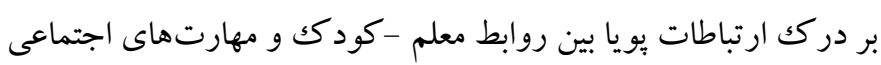
كود كان در دوره ييش دبستانى تأكيد كرده است (11)

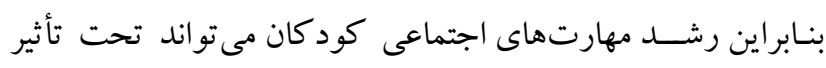

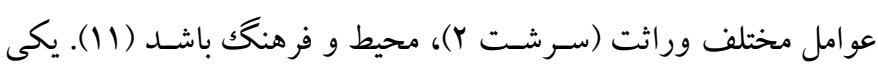

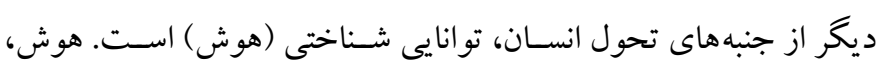

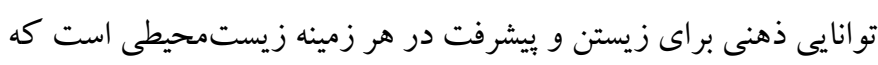

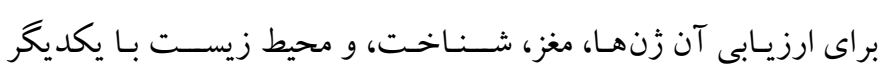

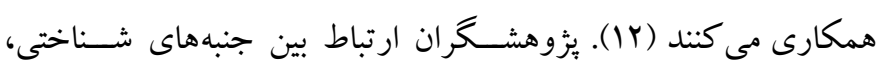
هيجانى، و اجتماعى كود كان باهوش را به خوبى تصريح كرده و اظهار

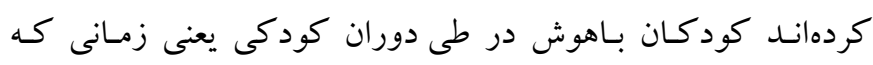

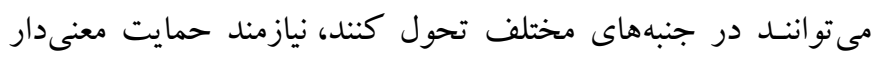

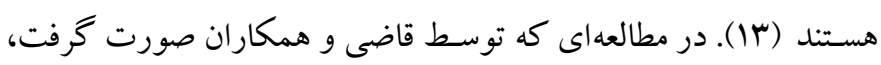

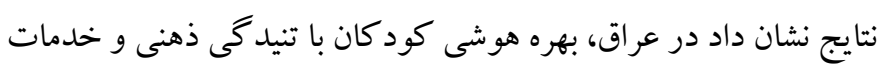
عمومى و محيط زندگى مرتبط است (If).

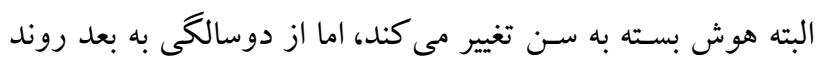

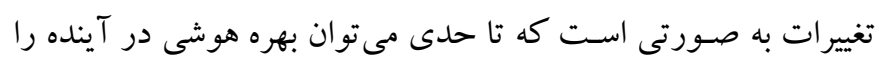

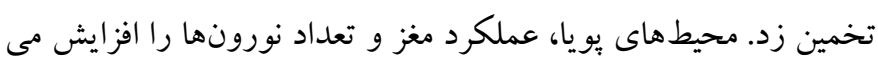

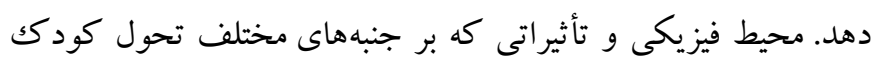

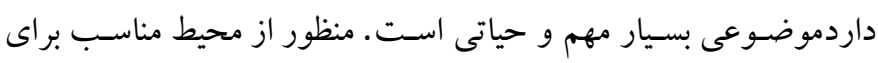

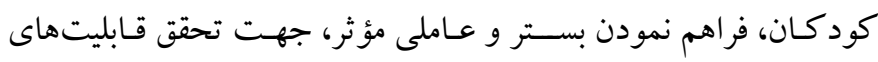

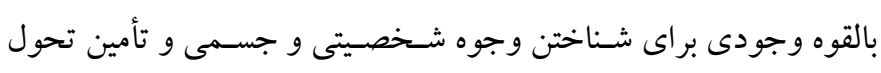

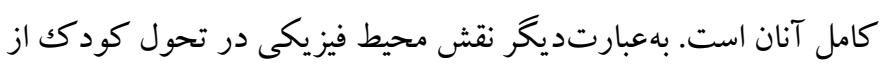

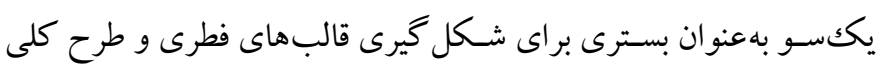

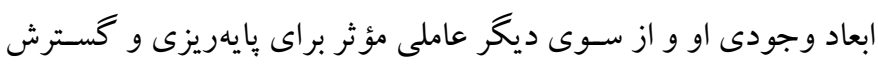

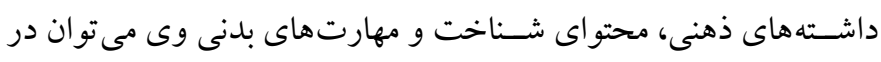

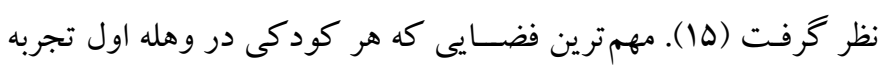
مى كند، خانه است. خانه، فضايى است كه در آن اصلى ترين دريافتهاى

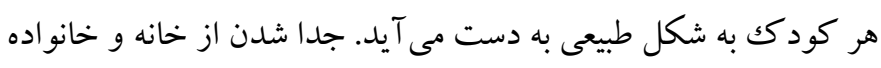

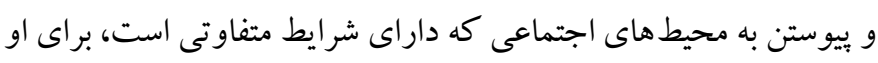

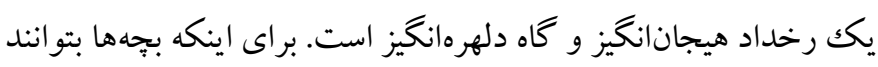

مقلهمه

بر اسـاس نظر متخصصـان ديد گاه باليدگى، زنتيكك مسئول اصلى تحول

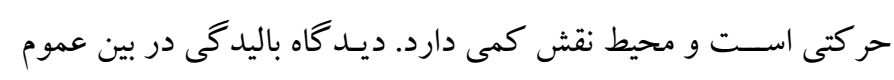

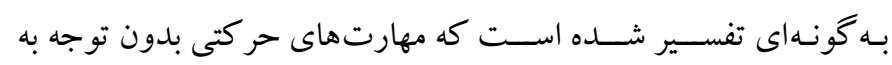

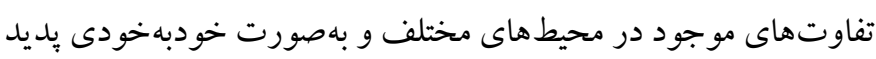

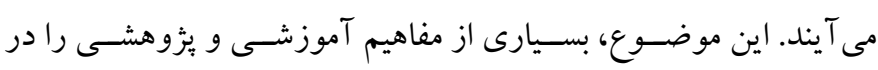

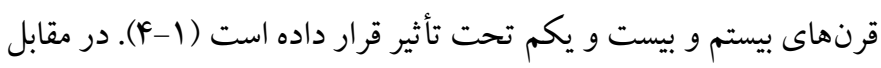

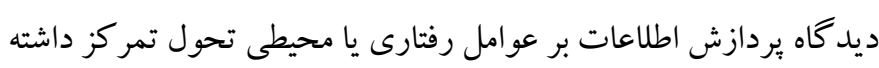

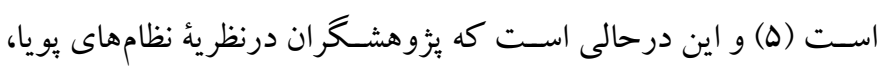
نقش تعاملى سه سيستم فرد، محيط، و تكليف را در فرايند تحول را مورد

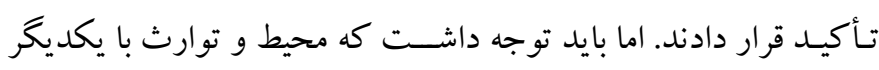

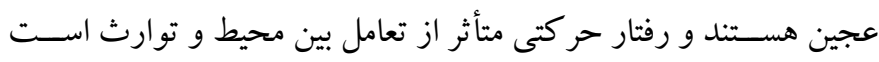

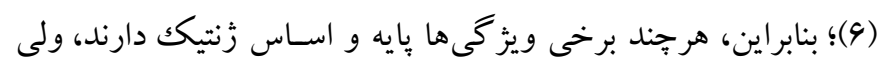

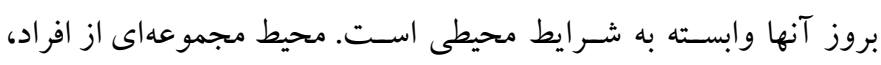

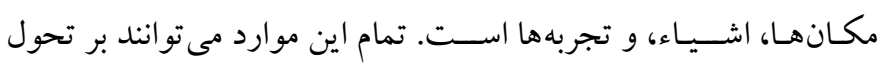
كود كك تأثير كذار باشـند. كودك نيازمند تجارب واقعى و همجِنين منابع الهام براى تحول اسـت. هرجه ارتباط يكك كودكك با مردم، مكانها، و يا

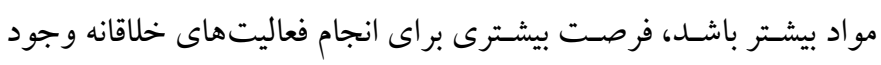

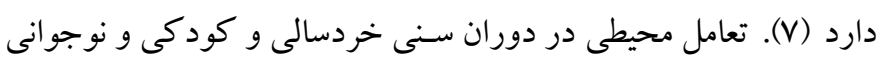

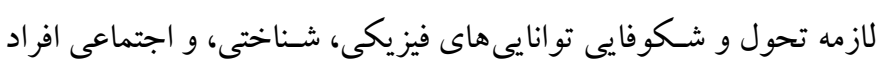

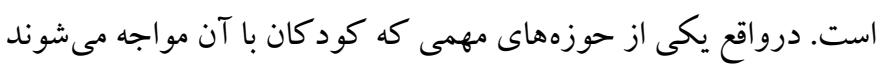

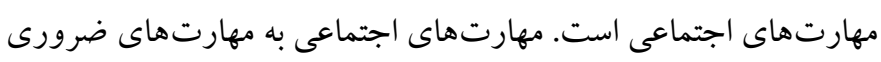

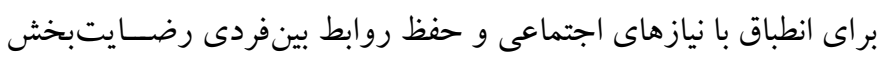

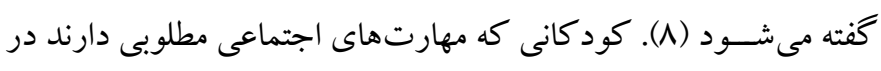

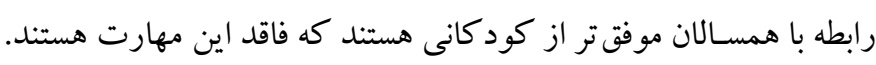

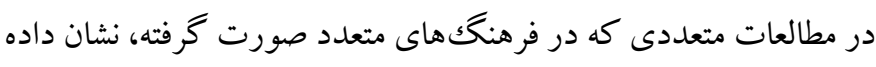
شده است كه كمبود محر ككهاى محيطى اثرات نامطلوبى بر روند تحول

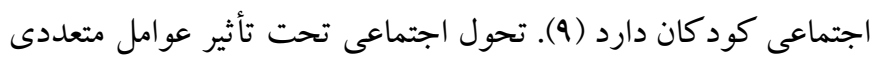

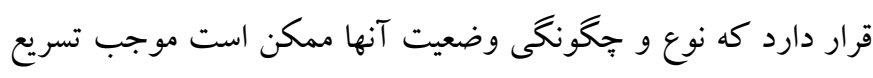

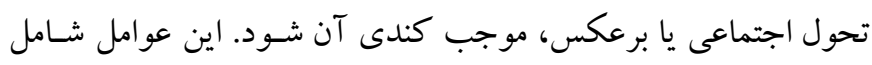

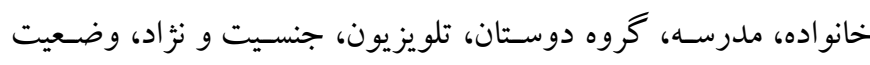

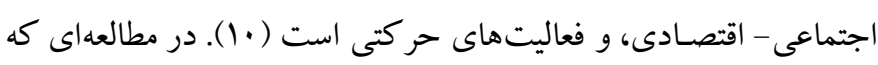


سـليقهاى متفاوت، و احسـاس محروميت از خانه و خانو اده باعث بروز

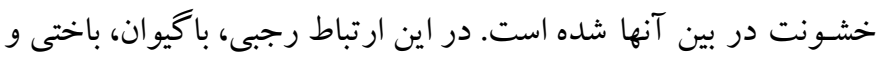

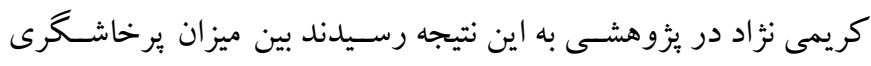

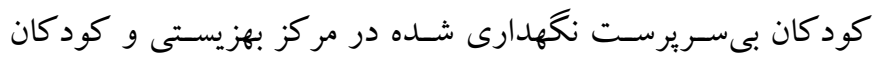

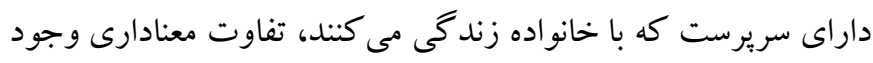

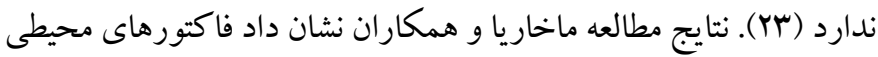
مختلف مـانــد محـل اقامت، تمرينات فيزيكى، در آمد خانواده، اشــتغال والدين، و تحصسيلات تا حد زيادى بر كيفيت زندگى كود كك تأثير دارد.

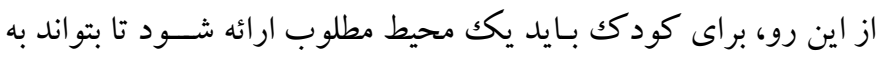

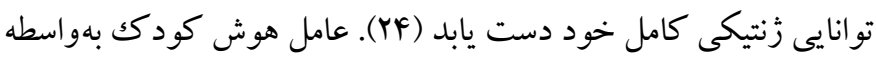

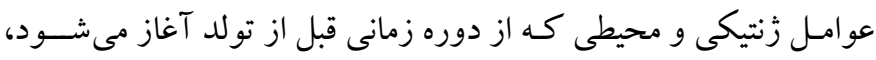
تعيين مىشـود. قنبرى و مقدس نشــان دادند كه كود كانى كه در محيط

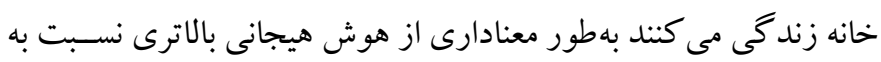

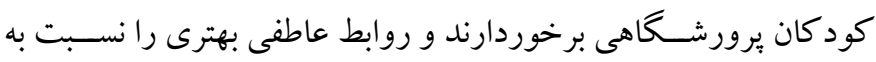

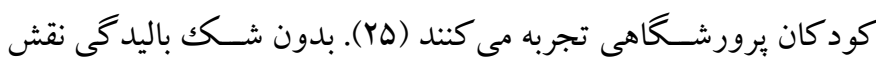

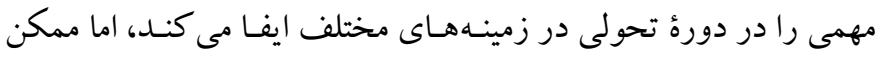
نيست كه آن تنها عامل مؤثر باشد. طبق ديد كاه سيستمى، تحول دماه دمه جانبه

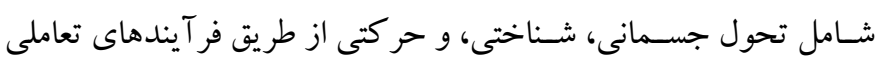

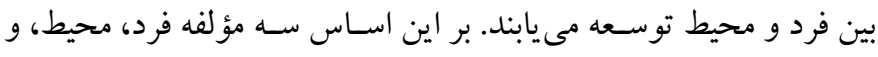

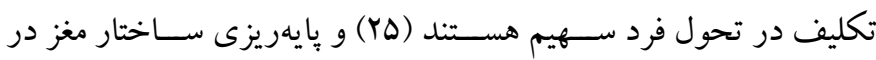
ابتداى زندگى و از طريق مجموعه بههمييوسته از تعامل بوياى بين عودامل

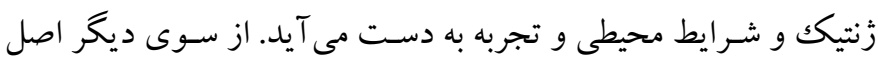

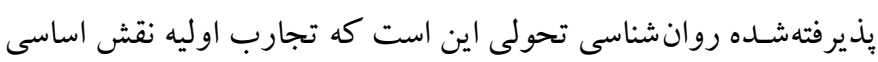

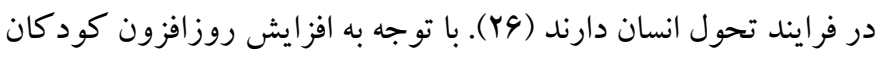

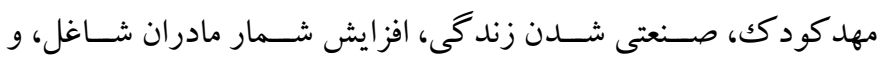
هم جنين نتايج متناقضى كه درباره نقش مهل كود ككها در تحول همه جانبه

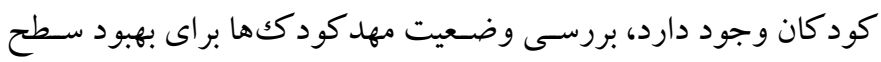
كيفيت و فضـاى بازى، بسـيار ضـرورى اسـت. از سـويى ديخر به دلايل

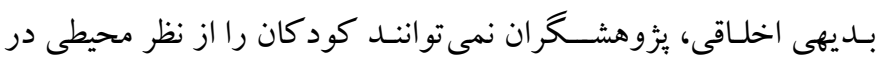

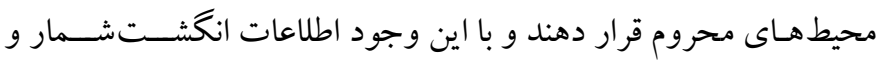

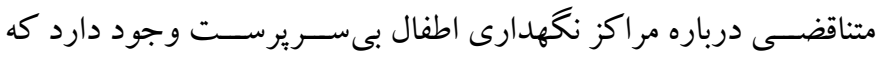

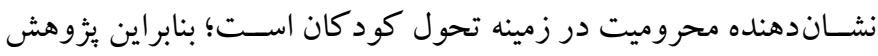

بـهـ آســانى خود را بـا محيط هـاى جديد تطبيق دهند، للزم اســت بتو انند

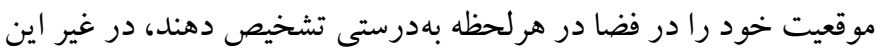

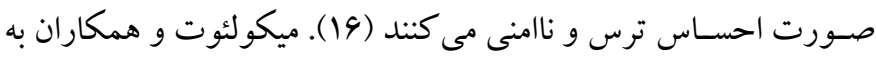

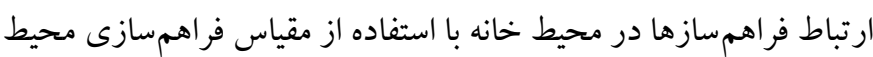

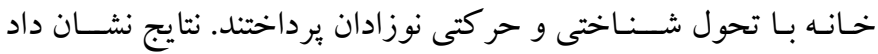
عملكرد شناختى ارتباط مثبتى با عملكرد حر كات ظريف دارد و همرجنين فر اهمسـازى محيط مى تواند تـأثير مثبى روى توانايى حر كتى و رفتار

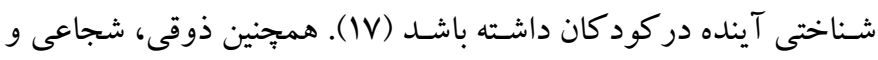

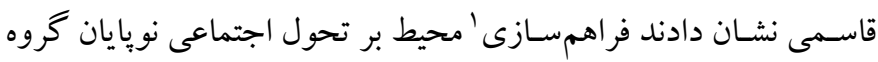

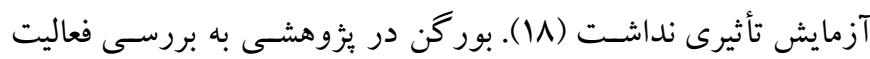

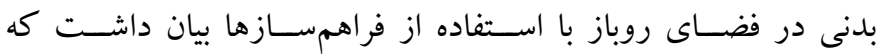
موقعيتها و فراهم سازهايى كه در فضاى باز براى كود كان وجود دارد

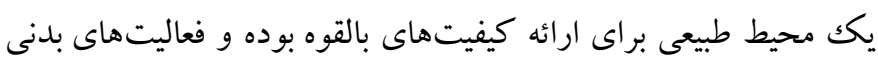

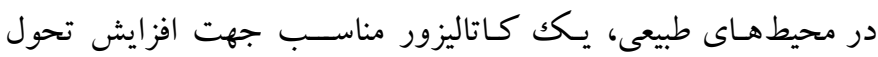
حر كتى كود كان است (19) محيط خانه، تنها موقعيت مؤثرى نيست كه كود كان اوقات خود را بال در آن سبرى مى كنند زيرا اين روزها بيش از •9٪ مادران آمريكايى كه

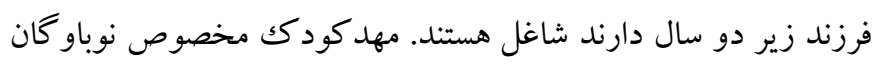

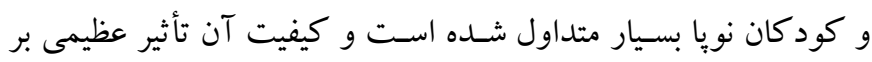

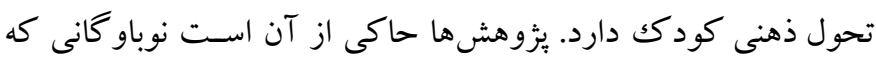

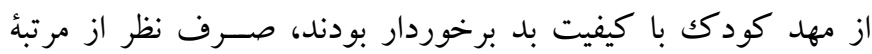

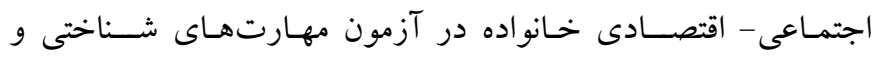

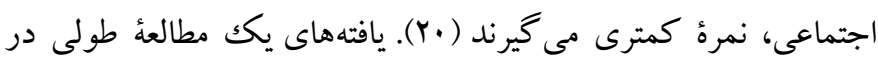

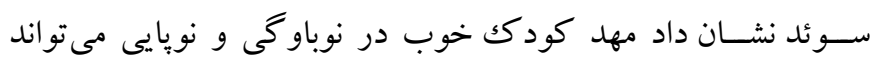

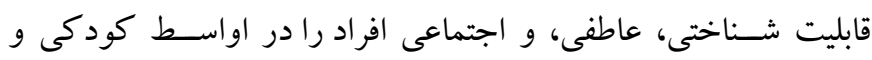
نو جوانى ارتقاء بخشد (YI).

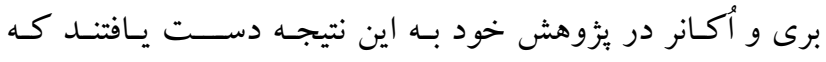

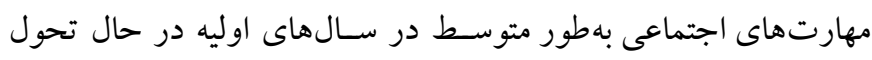

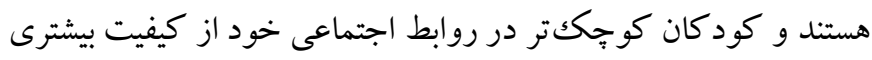

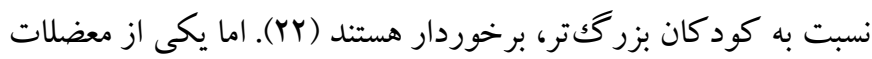

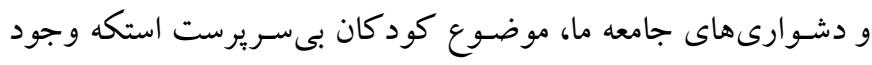

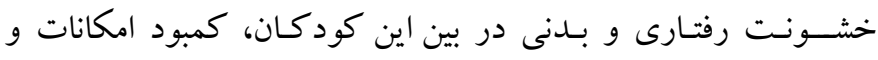


در كود كان مدرسـهاى بلزيكى كز ارش كردند (به نقل از YV). در ديخر

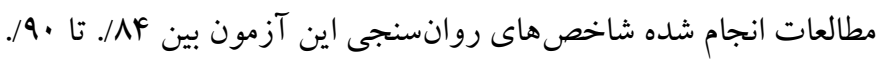

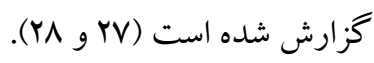

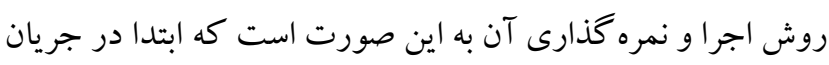

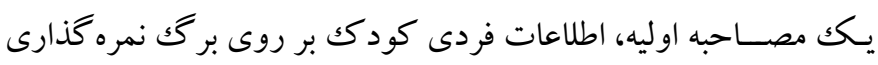

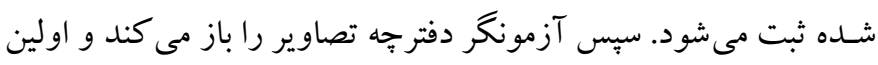

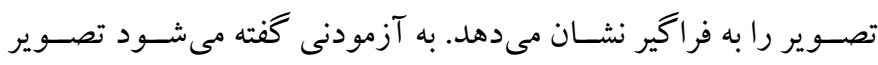

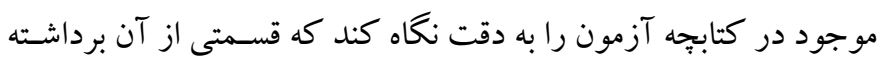

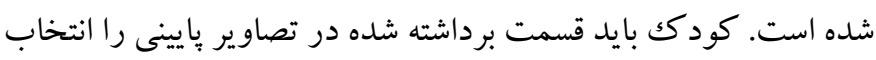

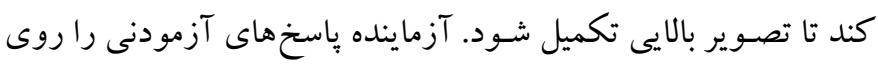

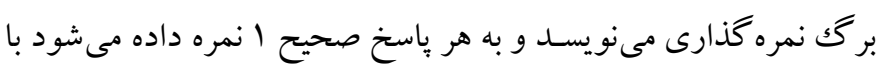

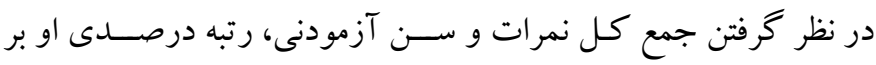

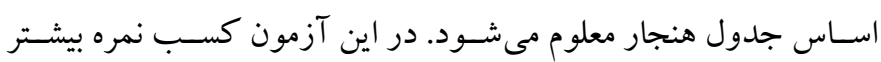

نشاندهنده هوش بالاتر آزمودنى است (YN).

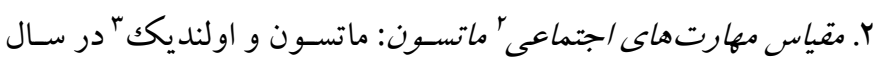

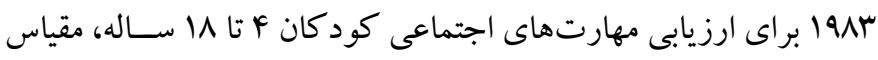

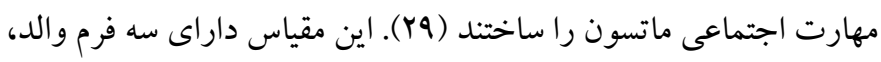
مربى، و دانش آموز اسـت. در اين يزٔوهش از فرم مربى استفاده شد. اين

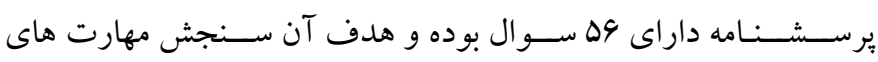
اجتمـاعى از ابعـاد مختلف (مهارتهـاى اجتمـاعى مناسـبـ، رفتارهاى

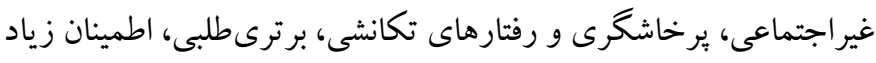

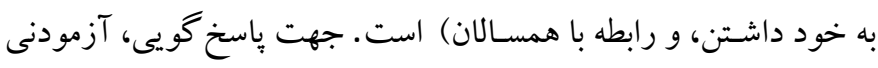

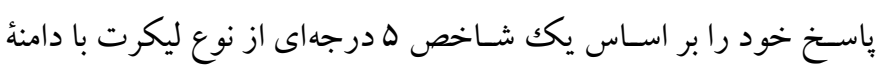

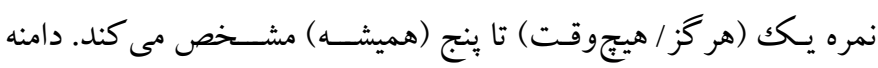

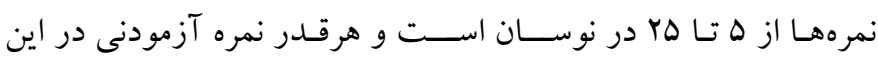

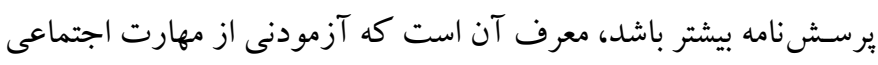

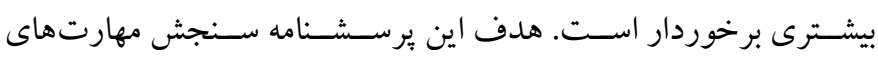

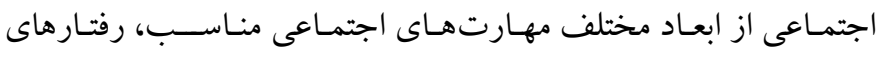

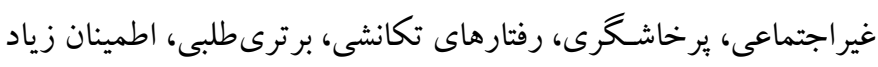

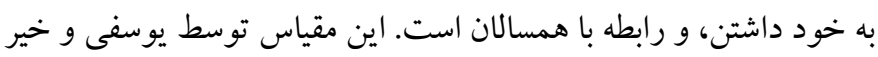

حـاضـر بـا هـدف تعيين نقش محيط تحولى كودكى بر بهره هوشـى و مهارتهاى اجتماعى كود كان F-9 سال شهر تهران طراحى شد تا بتوانيم

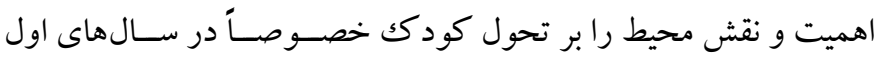
زندكى كودك مطالعه كنيم.

روش الف) طرح يزوهش و شـــ كت كنند كان: يزوهش حاضـر توصسيفى از نوع على - مقايسهاى اسـت كه بهصورت ميدانى اجرا شد. جامعه آمارى

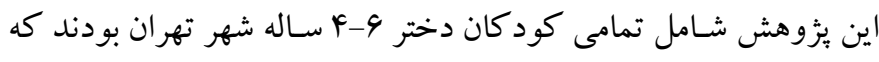

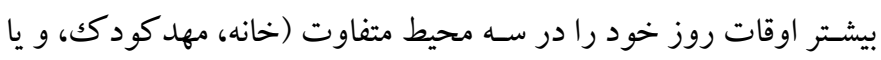

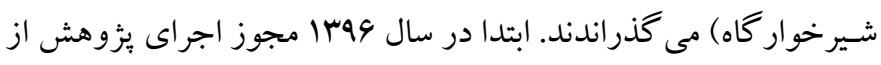

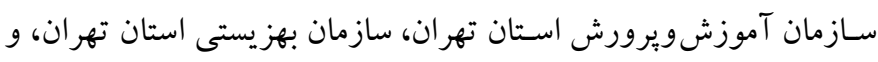

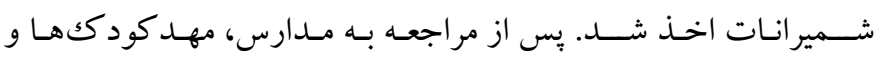

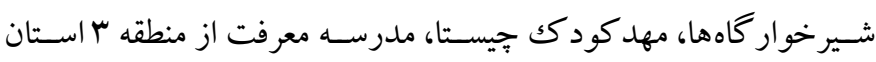

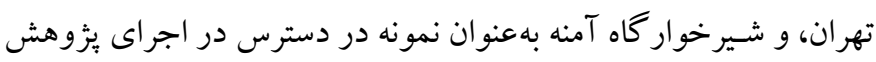

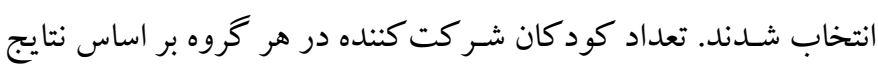

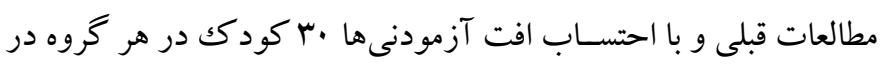

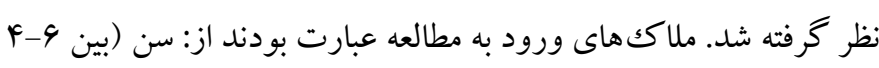

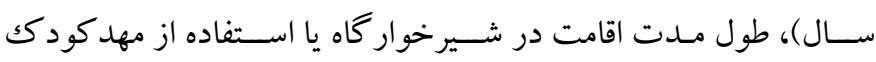
(حداقل 1/ ماه)، داشـتن سـلامت جسـمى، فاقد هر گونه مشـكل و اختلال ذهنى (كمتوانى ذهنى)، و ملاكك خروج، عدم انجام تكاليف توسط افراد نمونه بود.

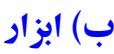

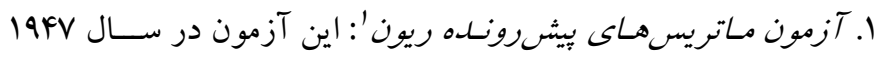

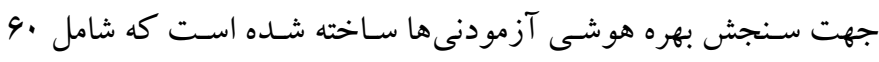

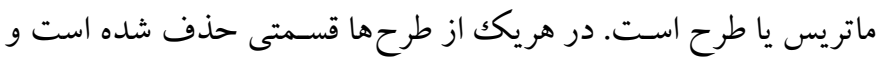

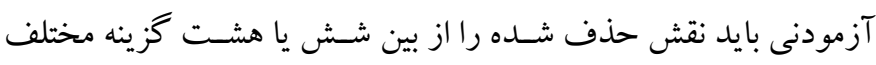

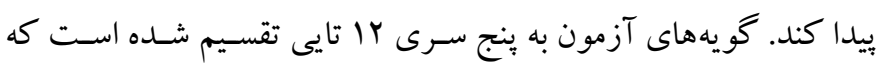

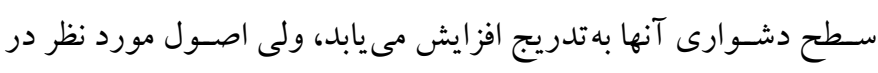

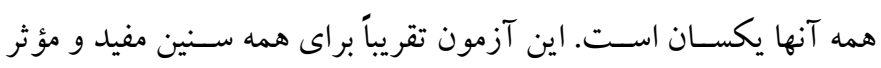

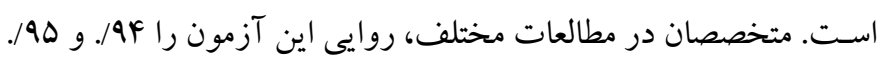


در يثوهش توسط كود كان كاملاً اختيارى بود و آنها اجازه داشتند در هر مرحله از ئزوهش كه از ادامه روند كار منصـرف شـوند از مطالعه خارج شـــــــــ از والـدين و مربيـان كود كان نيز جهت مشــاركت در بزوهش رضــايت نامه كتبى دريافت شـــد و در يايان ئزوهش نتايج هر كودكك به مربيان و والدين ارائه شـد. براى تجزيه و تحليل دادههاى به دسـت آمده در اين يزٔوهش از آزمون تحليل واريانس يككراهه استفاده شده است.

\section{بافتهن}

براى بررسـى نرمـاليتى توزيع دادههـا و تعيين نوع آزمون (يارامتريكك و نايارامتريكك) از آزمون كالمو گروف اســميرنف، براى بررسـى تجانس واريـانس هـا از آزمون لون، و براى آزمون فرضــيههاى صــفر از تحليل واريانس يككر اهه مستقل استفاده شد. ميانگين و انحراف استاندارد بهره هوشـى و مهـارت هـاى اجتمـاعى كود كان در ســهـه محيط مهد كودك، شيرخوار گاه، و خانه در جدول ا ارائه شده است.
ترجمه و با استفاده از ضريب آلفاى كرونباخ و تصنيف، اعتبار آن معادل

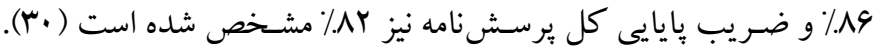
در مطالعه حاضر، ضريب بايايى و روايى مقياس مهارت اجتماعى V4٪ و

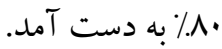
ج) روش اجرا: در ابتـاى كـار مجوزهاى لازم از اداره كل بهزيسـتى اســتان تهر ان و بهزيســى ناحيه شـمير انات كرفته شـــ و با حضــور به مهد كودك هاى منتخب و هماهنكى للزم با مسـئولين مهد و شيرخوار كاه و والدين كود كان در منزل، افراد نمونه بهصورت هدفمند و در دسترس انتخاب شـــند. براى والدين و مربيان در مورد اهميت و ضـــرورت اين مطالعه و نحوه تكميل برسـش نامه ها، توضسيح داده شـد. در برسـش نامه

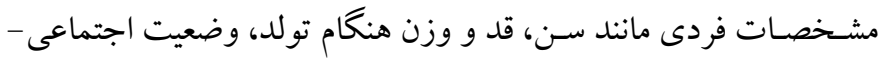
اقتصـادى، تحصـيلات و شـــايط شــلى والدين، محل زندكى، سـابقه بيمارى، و نظاير آن ذكر شـده بود كه مىبايست توسط اوليا و يا مربيان ياسخ داده مى شد. در مرحله بعد مابقى يرسشنامههاى ذكر شده در بخش ابزار روى افراد نمونه اجرا شد. جهت رعايت ملاحظات اخلاقى، مشاركت

جدول ا: ميانكين، انحراف معيار و سطح معنادارى نرماليتى بهره هوشى و مهارتهاى اجتماعى كود كان محيط خانه، مهد، و شيرخوار كاه

\begin{tabular}{|c|c|c|c|c|}
\hline نرماليتى دادهها & محيط شيرخوار كاه & محيط مهد & محيط خانه & متغير \\
\hline $\mathrm{p}=\cdot / \mathrm{V} \wedge$ & $V \psi / \Lambda \cdot \pm r \cdot / \Delta r$ & $|r / r \cdot \pm| F / \Delta q$ & $1 \cdots / r q \pm \mid F / r V$ & بهره هوشى \\
\hline $\mathrm{p}=\cdot /{ }_{F}$ & $\mid \Delta / \Delta \Psi \pm r / r \Delta$ & $M / F T \pm Y / Y r$ & IV/IG $\pm r / A r$ & مهارت اجتماعى \\
\hline
\end{tabular}

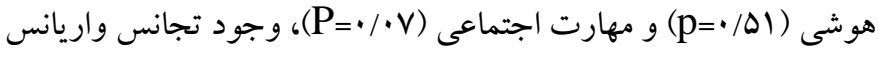
را تـأييـد كرد؛ بنـابراين براى تحليـل دادههـا از آزمون تحليـل واريـانس يككراهه اسـتفاده شـد. در جدول ب نتايج تحليل واريانس يككر اهه براى متغير بهره هوشى ارائه شده است.
يافته هاى ارائه شده در جدول ا نشان داد بيشترين نمره بهره هوشى و مهارت اجتماعى مربوط به كود كان مهد و كمترين نمره بهره هوشـى و مهارت اجتماعى مربوط به كود كان شيرخوار كاه بوده است. در متغيرهاى بهره هوشى، مهارت هاى اجتماعى، نتايج آزمون كولموكروف اسميرنف نشــان داد توزيع دادههـا طبيعى و نتايج آزمون لوين براى متغيرهاى بهره

جدول r: مقايسه ميانكين بهره هوشى كود كان در محيط مهد، خانه، شيرخوار كاه

\begin{tabular}{|c|c|c|c|c|c|}
\hline سطح معنادارى & $\mathbf{F}$ & ميانكين مجذورات & درجات آزادى & مجموع مجذورات & منبع تغييرات \\
\hline.$/ .1$ & $\mid r Y / 99$ & $r .949 / 9 \mathrm{~V}$ & $r$ & $91 \mathrm{rVT} / \mathrm{rd}$ & بين گروهى \\
\hline - & - & $r F q / 19$ & AV & r19V9/99 & درون گروهى \\
\hline- & - & - & 19 & $\Lambda r q \Delta \cdot / r r$ & خطاى كل \\
\hline
\end{tabular}

(F (Y تفـاوت معنادار اســت. براى تفاوت هاى زوجى از آزمون تعقيبى توكى استفاده شد (جدول r).
نتايج تحليل واريانس يككراهه نشان داد بين بهره هوشى كود كان در

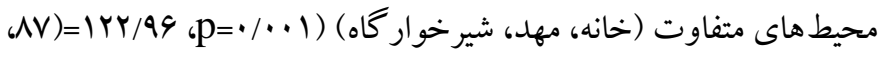


جدول ": مقايسه زوجى بهره هوشى آزمودنى ها در سه كروه كود كان ساكن مهد كودكى، شيرخوار كاه، و خانه

\begin{tabular}{|c|c|c|c|}
\hline كود كان شيرخوار كاه & كود كان مهد كود كى & كود كان محيط خانه & متغير: بهره هوشى \\
\hline.$\cdots 1$ &.$/ \cdot 1$ & ----------- & كود كان محيط خانه \\
\hline.$/ . \cdot 1$ & ------_------_- &.$/ .1$ & كود كان مهدكو دك \\
\hline -_-_-_-_-_-_-_ & $\cdot / \cdot \cdot 1$ & $\cdot / \cdot \cdot 1$ & كود كان شيرخوار كاه \\
\hline
\end{tabular}

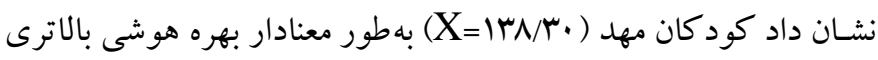

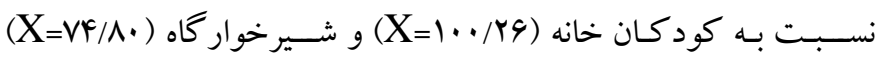

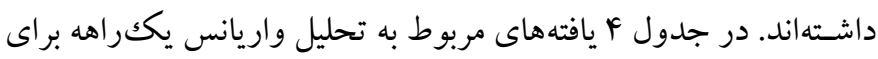
متغير مهارت اجتماعى ارائه شده است.
مقايسـه هاى زوجى با اسـتفاده از آزمون تعقيبى توكى نشـان داد بين

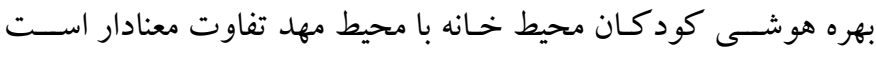

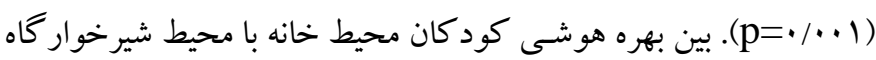

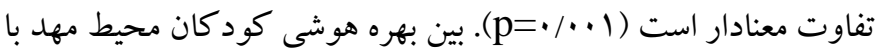

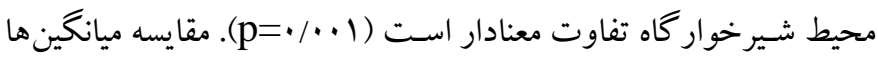

جدول ع: مقايسه ميانكين مهارت اجتماعى كود كان در محيط مهد، خانه، شيرخوار كاه

\begin{tabular}{|c|c|c|c|c|c|}
\hline سطح معنادارى & $\mathbf{F}$ & ميانكين مجذورات & درجات آزادى & مجموع مجذورات & منبع تغييرات \\
\hline$\cdot / \cdot 1$ & $\Lambda / \cdot \Delta$ & $9 \pi / 41$ & $r$ & IYG/AY & بين گروهى \\
\hline - & - & $\mathrm{V} / A \mathrm{~V}$ & AV & $9 \wedge \Delta / \cdot \cdot$ & درون گروهى \\
\hline - & - & - & $\wedge 9$ & AII/Ar & خطاى كل \\
\hline
\end{tabular}

اســت. براى تفــاوت هاى زوجى از آزمون تعقيبى توكى اســتفاده شـــد

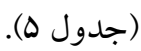

نتايج تحليل واريانس يككراهه براى متغير مهارت اجتماعى كود كان نشــان داد بين مهارت اجتماعى كود كان در محيطهاى متفاوت (خانه،

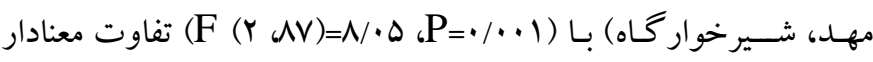

جدول 0: مقايسه زوجى مهارت اجتماعى آزمودنى ها در سه كروه كودكان ساكن مهد كودكى، شيرخواركاه و خانه

\begin{tabular}{|c|c|c|c|}
\hline كود كان شيرخوار كاه & كود كان مهد كودكى & كود كان محيط خانه & متغير: مهارت اجتماعى \\
\hline$\cdot / \cdot 0$ &.$/ 19$ & ----------- & كو د كان محيط خانه \\
\hline.$/ \cdot 1$ & --------------- &.$/ 19$ & كو د كان مهد كو دك \\
\hline ------_------ & $\cdot / \cdot \cdot 1$ & $\cdot / \cdot \Delta$ & كود كان شيرخوار كاه \\
\hline
\end{tabular}

\section{بحث و نتيجه كيرى}

هدف از انجام يزوهش حاضسر بررسى نقش محيط تحول كودكى (خانه، مهلد، و شـيرخوار گاه) بر بهره هوشى و مهارت هاى اجتماعى كود كان 9F كودكى در آن برورش مى يـابسـ بر بهره هوشـى كودكـان تـأثير دارد و

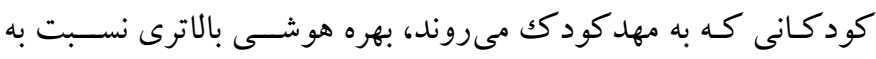

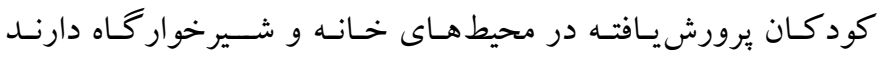

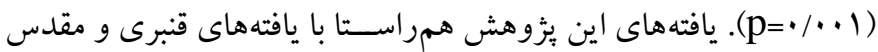

نتـايج آزمون توكى در جـدول ه نشـــان داد بين مهـارت اجتمـاعى كود كان محيط خانه با محيط مهل تفاوت معنادار نيسـت (19 / مهـارت اجتمـاعى كودكـان محيط خـانه با محيط شــيرخوار كاه تفاوت معنادار اســت (ه •/p=•) و بين مهارت اجتماعى كود كان محيط مهد با

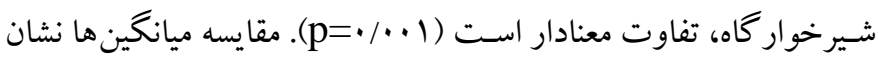

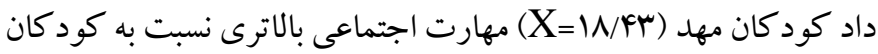

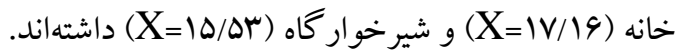


تخصص للازم مربيان برخى مراكز مهد كودك باشد. همجنين استفاده از

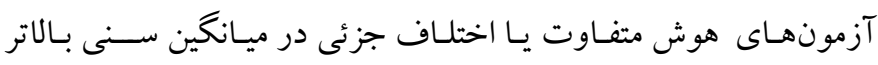

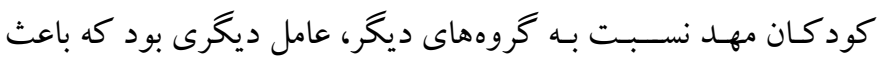

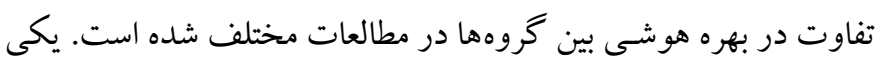

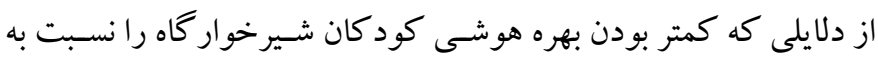

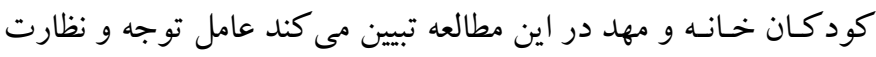

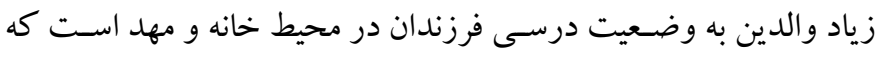

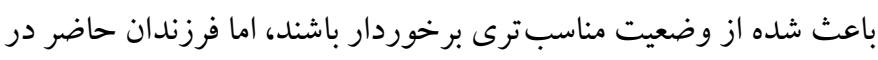
شيرخوار كاهها، از خنين نعمتى محروم هستند. نتـايج مربوط بـه مهـارتهـاى اجتمـاعى نيز نشــان داد بين مهـارت

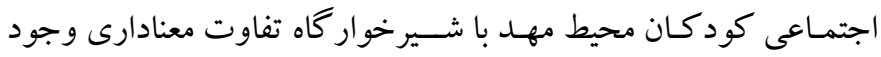

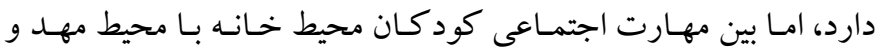

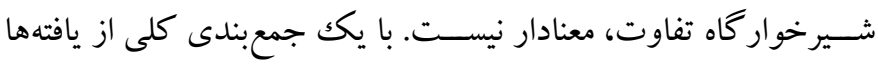

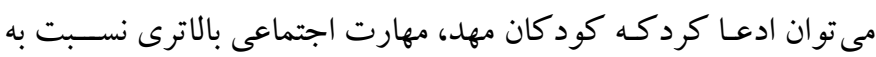

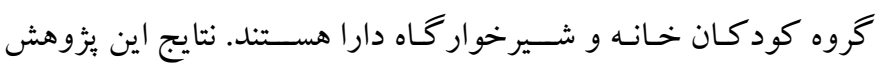

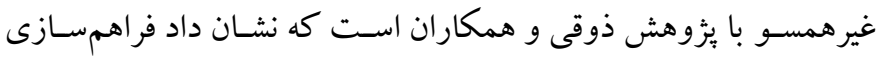
محيط بر تحول اجتماعى نويايان گروه آزمايش تأثير نداشت (1) (1). شايد

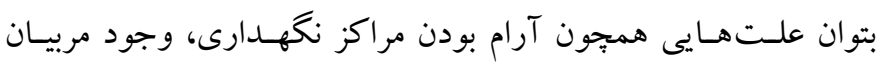

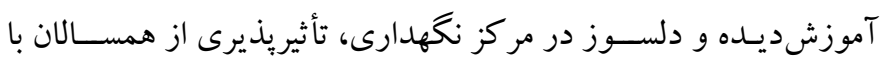
توجه به سن را در ميزان تحول اجتماعى اين كود كان مؤثر دانست.

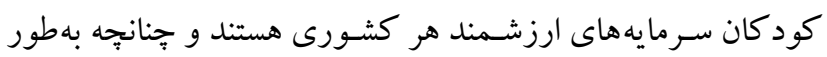

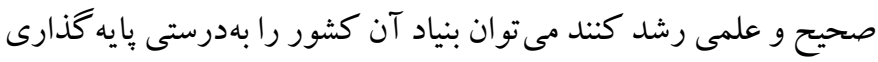

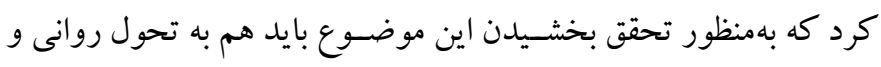
عاطفى و هم به تحول جسـمى آنها اهميت داده شـود (Yr). در بـ اين ميان

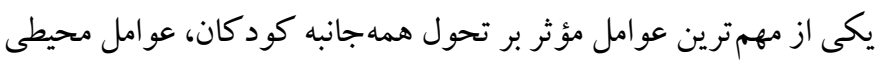

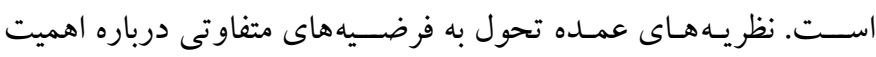

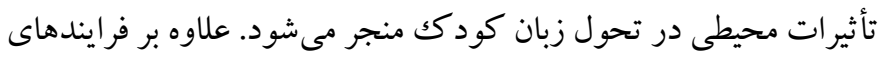

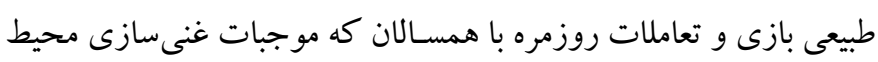

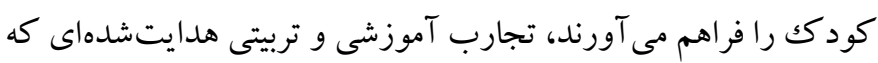
توســط محيط مهـدكودك از طريق اجراى برنامههاى آموزشسى فر فراهم

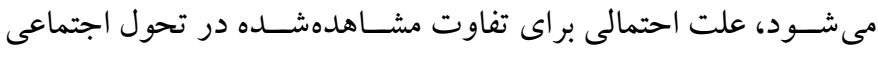
كود كان مهلد رفته و نرفته در اين مطالعه بوده است.
(YD)، و ميكولئوت و همكاران (IV) اســت. قنبرى و مقدس در يُزوهش خود نتيجـه گرفتند كو د كانى كه در محيطهاى خانه با اعضسـاى خانو اده

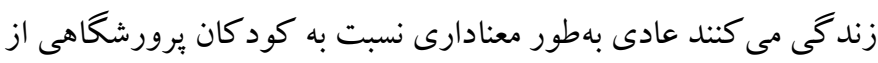

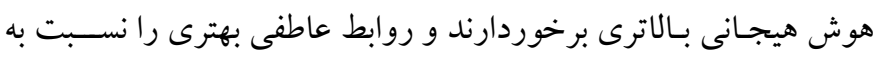

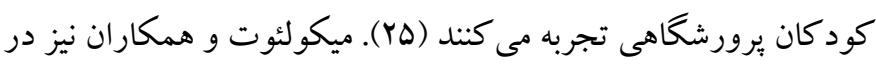

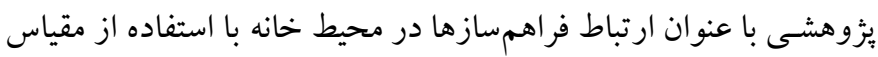
فر اهم سـازى محيط خانه با تحول شناختى و حر كتى نوزادان به اين نتيجه

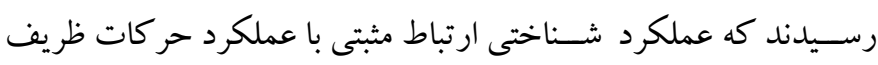

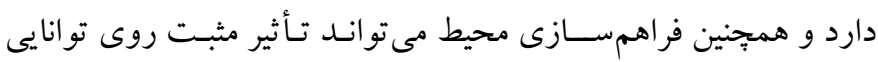

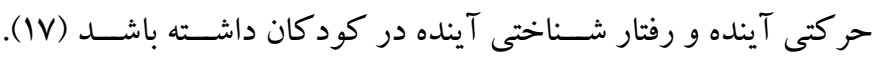

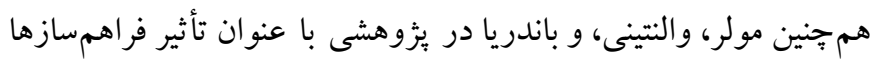

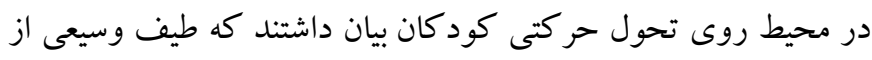

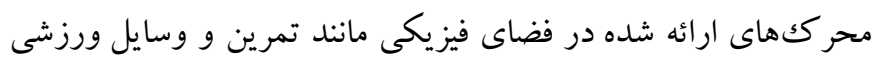

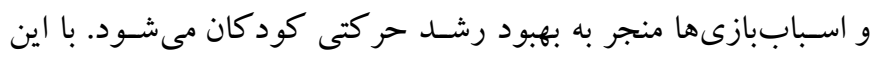

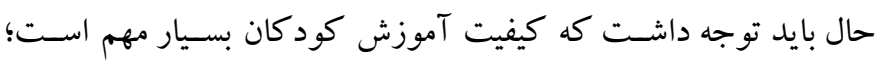

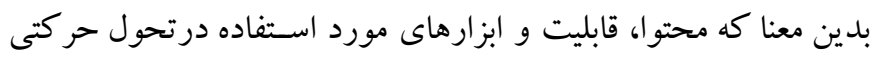
كودك بسيار مهم است (Iآ)

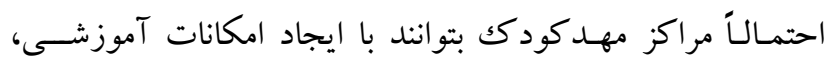

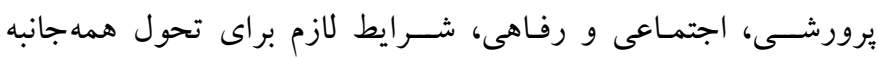

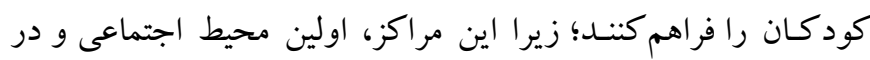
واقع يلى بين خانه و اجتماع بزركى اسـت كه كودك به به آن تعلق دارد.

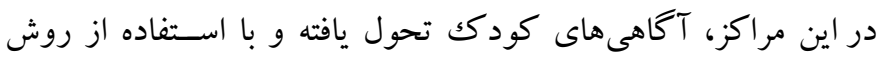

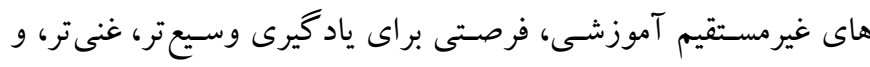

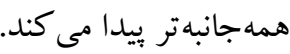

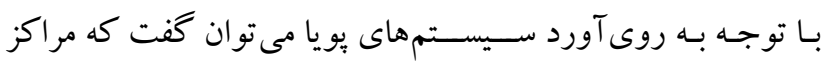

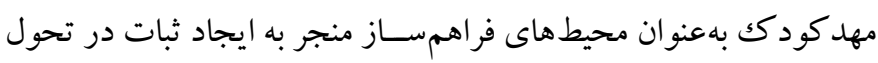

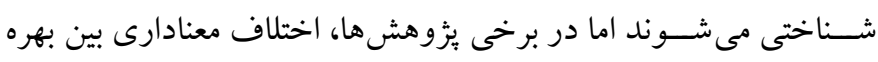

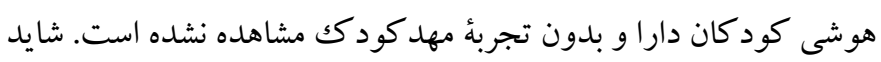

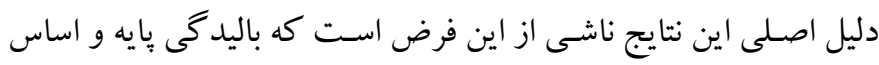

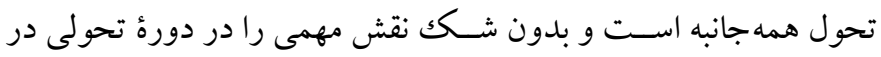

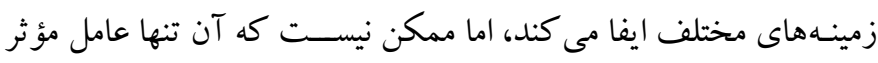

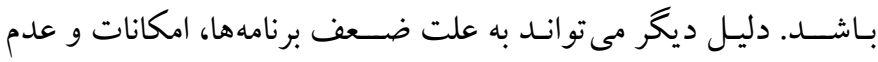


آموزشى و ارتباطات اجتماعى، كود كان را با فرصتهاى بيشـترى براى

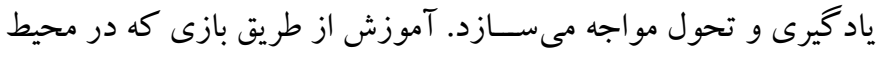

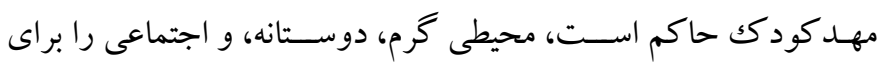

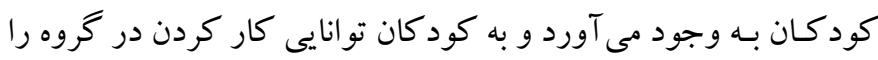

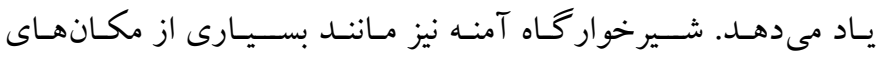

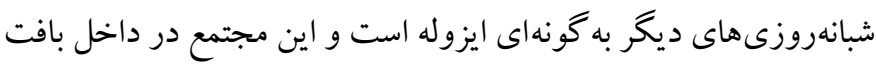

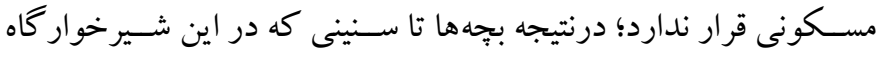

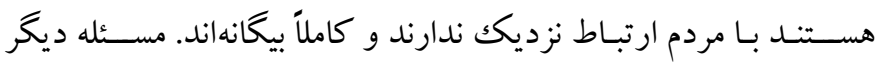

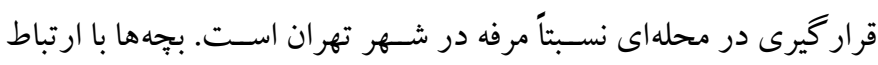
كمى كه به بهانه هاى مختلف با مردم دارند، ارتباطشـان بيشتر فقط با قشر مرك

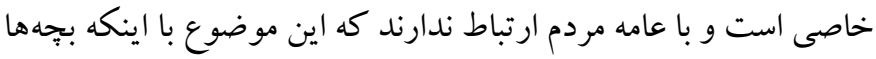

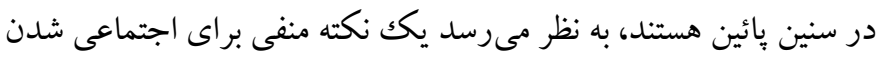

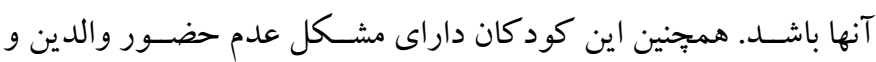

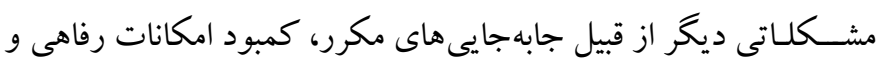

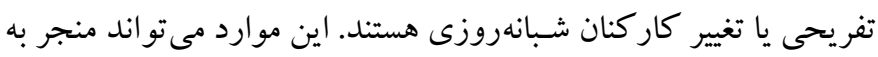
احســاس بى ثبـاتى، عـدم امنيت، يا عدم ارضــاى نيازهاى مختلفى مانند نيازهاى اجتماعى شود. بىثباتى و عدم امنيت خود باعث بروز احساساتى

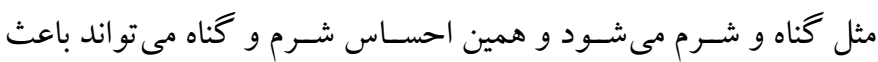
ضعف در مهارتهاى اجتماعى اين كود كان شود. از محدوديت يزوهش حاضسر مى توان به انتخاب نمونه در دسـترس

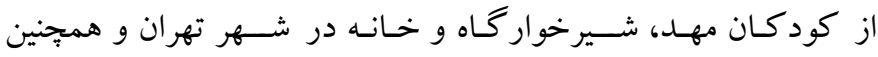

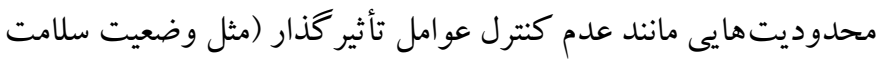

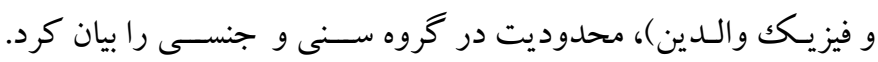
ييشنهاد مى شود كه يزوهش حاضر بر اساس محدوديتهاى ذكرشده در

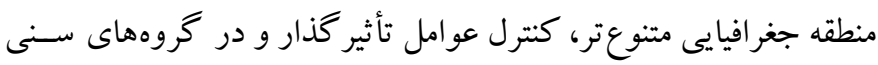

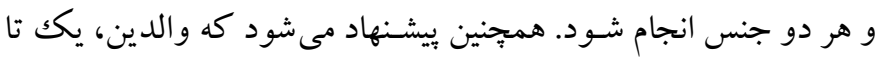

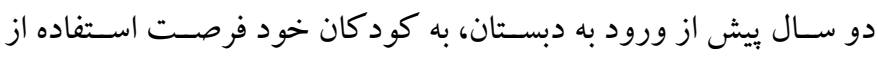

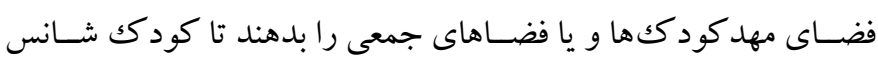
ياد گيرى بيشتر و شكوفايى تحول هوشى قبل از ورود به مدرسه راد راد داشته

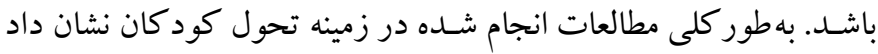

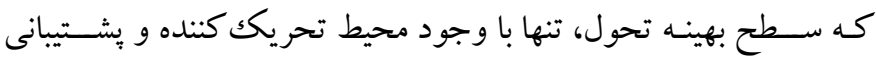
زمينهاى قوى حاصل مىشود و بيشازيش بر اين تأكيد داشتهاند كه يكك
كود كان در مهد مباحث آموزشسى و رفتارهاى اجتماعى را از طريق

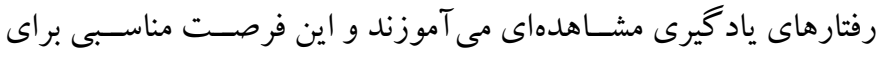

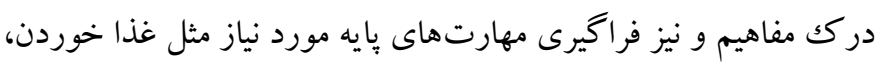

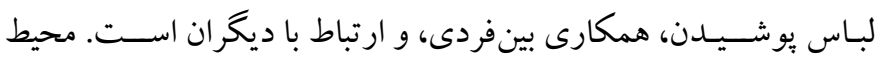

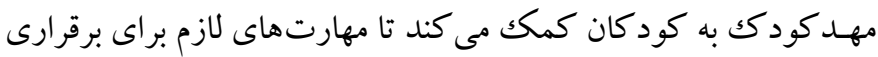

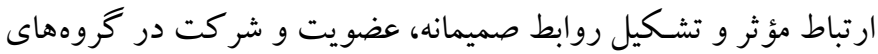

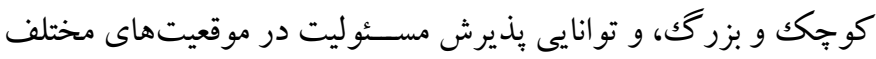

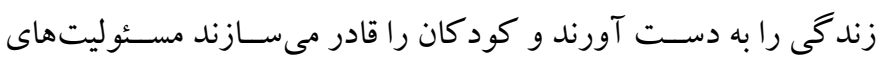

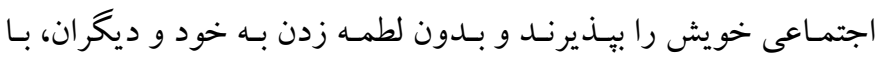

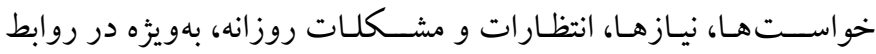
بين فردى به شكل مؤثرى روبرو شوند (· (1). يرلمـان و همكاران دو هدف مهدهاى كود كك را تحول مهارتهاى

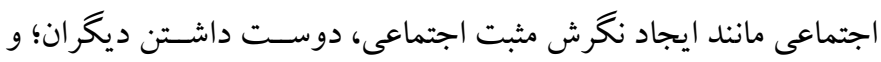

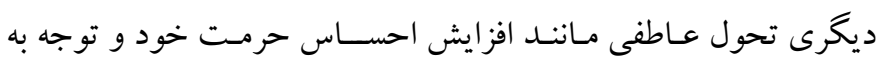

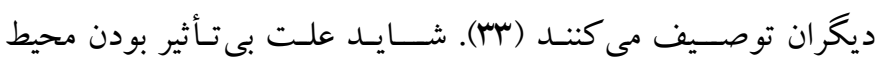

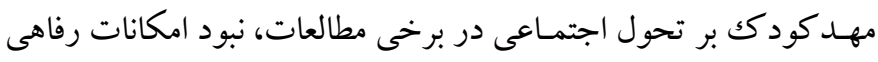

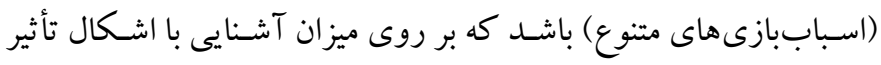

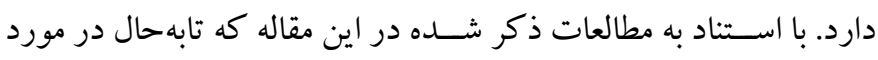

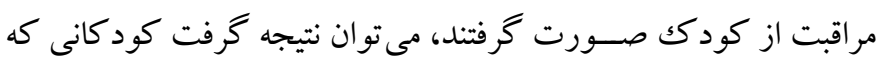

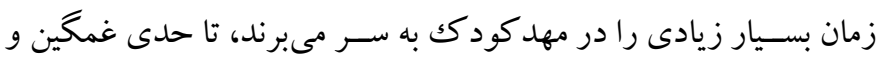

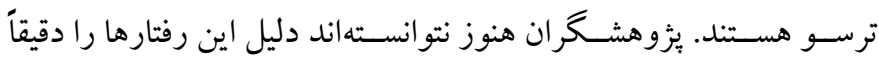

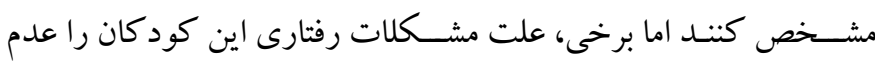
توجه به كودك و يا عدم توجه مســـولان مهد كو دككها عنوان مى كنند.

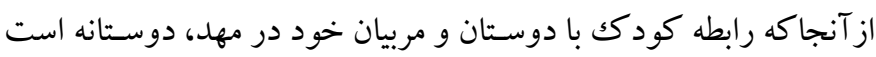
تأثيريذيرى و الكوبردارى از آنان در قياس با محيط خانواده، بيشتر است.

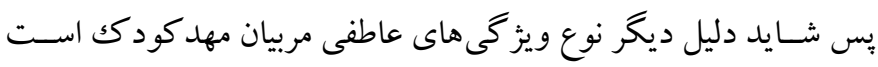

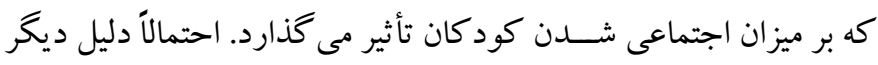
عدم تخصص تربيتى و آموزش مربيان بر نحوه استفاده صحيح از زبان و

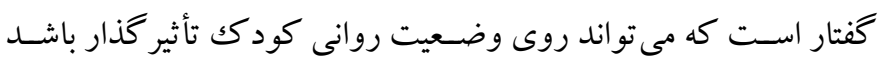

( $(M F, M)$

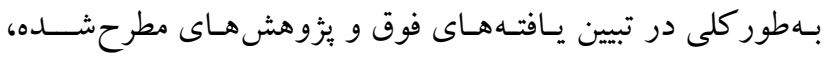

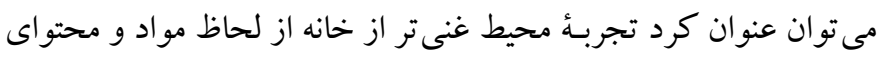


در تاريخ 99/9/49 از يـاياننامه خود با درجه عالى دفاع كرده اســت. همجنين

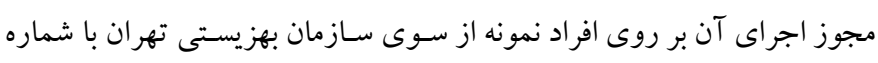

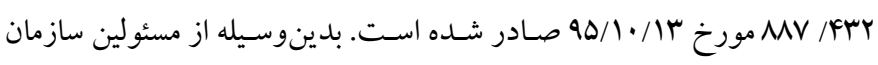

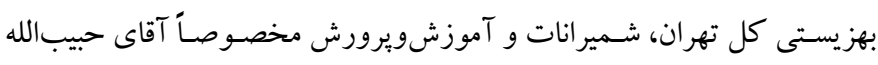

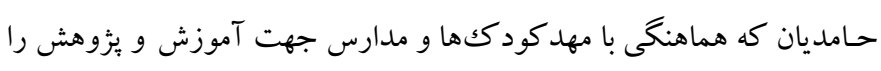

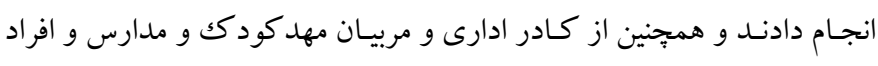

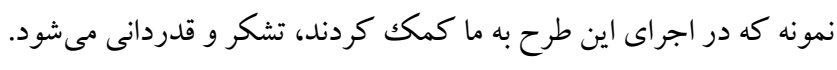
تضـاد منافع: اين يزوهش هيج گونه تضـاد منافعى براى نويســد كان به دنبال

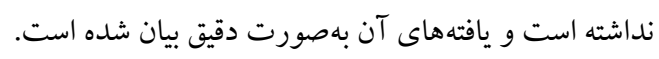

محيط تسهيل كننده، نقش مهمى در تحول ايفا مى كند. بيشتر يزوهشگر ان

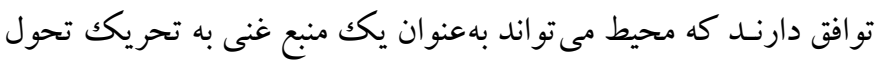

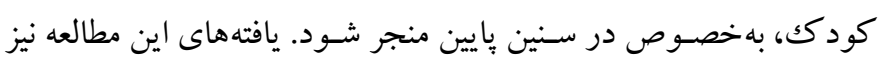

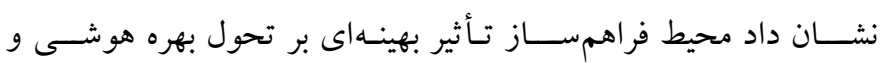
مهارتهـاى اجتمـاعى كودكـان F-9 ســاله دارد و كود كان مهل، بهره هوشى و مهارت اجتماعى بالاترى در مقايسه با ساير كود كان دارا هستند. تشكر و قدردانى: اين يثزوهش بر گرفته از بايانامه كارشناسى ارشد خانم ليلا

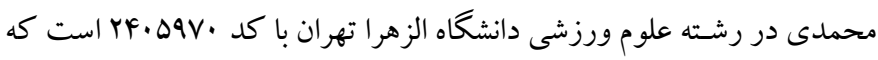




\section{References}

1. Gharaei F, Arabameri E, Huminiyan D. The effect of (perceptual-motor and music) enrichment of environment on age equivalents of gross and fine motor movements in 5-8-month-old infants. Journal of Development and Motor Learning. 2014; 6(1): 75-89. [Persian]. [Link]

2. Hsieh Y-H, Hwang A-W, Liao H-F, Chen P-C, Hsieh W-S, Chu P-Y. Psychometric properties of a Chinese version of the home environment measure for motor development. Disabil Rehabil. 2011; 33(25-26): 2454-2463. [Link]

3. Caçola P, Gabbard C, Santos DCC, Batistela ACT. Development of the affordances in the home environment for motor development-infant scale. Pediatr Int. 2011; 53(6): 820-825. [Link]

4. Mori S, Nakamoto H, Mizuochi H, Ikudome S, Gabbard C. Influence of affordances in the home environment on motor development of young children in Japan. Child Dev Res. 2013; 898406: 1-5. [Link]

5. Freitas TCB, Gabbard C, Caçola P, Montebelo MIL, Santos DCC. Family socioeconomic status and the provision of motor affordances in the home. Braz $\mathrm{J}$ Phys Ther. 2013; 17(4): 319-327. [Link]

6. Laaksoharju T, Rappe E, Kaivola T. Garden affordances for social learning, play, and for building nature-child relationship. Urban For Urban Green. 2012; 11(2): 195-203. [Link]

7. Musaad SMA, Speirs KE, Hayes JT, Mobley AR, Fitzgerald N, Jones BL, et al. The impact of environmental, parental and child factors on healthrelated behaviors among low-income children. Appetite. 2017; 112: 260-271. [Link]

8. Ashori M, Yazdanipour M. Investigation of the effectiveness of group play therapy training with cognitive- behavioral approach on the social skills of students with intellectual disability. Archives of Rehabilitation. 2018; 19(3): 262-275. [Persian]. [Link]

9. Abri S, Hajyousefi A, Hajbabayi H, Rahgozar M. Comparison of social development between 3-6 years old children who use rural child care center services and who don't. Social Welfare Quarterly. 2011; 11(41): 343-368. [Persian]. [Link]

10. Behroz-Sarcheshmeh S, Karimi M, Mahmoudi F, Shaghaghi P, Jalil-Abkenar SS. Effect of training of life skills on social skills of high school students with intellectual disabilities. Practice in Clinical Psychology. 2017; 5(3): 177-186. [Link]
11. Wu Z, Hu BY, Fan X, Zhang X, Zhang J. The associations between social skills and teacher-child relationships: A longitudinal study among Chinese preschool children. Child Youth Serv Rev. 2018; 88: 582-590. [Link]

12. Rinaldi L, Karmiloff-Smith A. Intelligence as a developing function: a neuroconstructivist approach. J Intell. 2017; 5(2): 18. [Link]

13. Narimani M, Pouresmali A, Andalib M. A comparison of parenting styles and eating disorders in normal and bright students. Journal of School Psychology. 2013; 2(2): 138-154. [Persian]. [Link]

14. Ghazi HF, Isa ZM, Aljunid S, Shah SA, Tamil AM, Abdalqader MA. The negative impact of living environment on intelligence quotient of primary school children in Baghdad City, Iraq: a crosssectional study. BMC Public Health. 2012; 12: 562. [Link]

15. Bräuninger I. The efficacy of dance movement therapy group on improvement of quality of life: A randomized controlled trial. Arts Psychother. 2012; 39(4): 296-303. [Link]

16. Edens KM, Potter EF. An exploratory look at the relationships among math skills, motivational factors and activity choice. Early Child Educ J. 2013; 41(3): 235-243. [Link]

17. Miquelote AF, Santos DCC, Caçola PM, Montebelo MI de L, Gabbard C. Effect of the home environment on motor and cognitive behavior of infants. Infant Behav Dev. 2012; 35(3): 329-334. [Link]

18. Zoqi A, Shojaei M, Ghasemi A. The effect of an environment motor affordance intervention on social development of toddlers. Journal of Development and Motor Learning. 2016; 8(1): 193-207. [Persian]. [Link]

19. Bjørgen K. Physical activity in light of affordances in outdoor environments: qualitative observation studies of 3-5 years olds in kindergarten. SpringerPlus. 2016; 5(1): 950. [Link]

20. Carolan BV. Extracurricular activities and achievement growth in kindergarten through first grade: The mediating role of non-cognitive skills. Early Child Res Q. 2018; 45: 131-142. [Link]

21. Conger D, Gibbs CR, Uchikoshi Y, Winsler A. New benefits of public school pre-kindergarten programs: Early school stability, grade promotion, and exit from ELL services. Early Child Res Q. 2019; 48: 26-35. [Link]

22. Berry D, O'Connor E. Behavioral risk, teacher-child relationships, and social skill development across middle childhood: A child-by-environment analysis of 
change. J Appl Dev Psychol. 2010; 31(1): 1-14. [Link]

23. Rajabi M, Bagiyan MJ, Bakhti M, Kariminejad K. Comparison of mental health indicators in orphaned children held centers with children deposited to relatives in Lorestan province. Journal of Pediatric Nursing. 2017; 4(1): 36-42. [Persian]. [Link]

24. Makharia A, Nagarajan A, Mishra A, Peddisetty S, Chahal D, Singh Y. Effect of environmental factors on intelligence quotient of children. Ind Psychiatry J. 2016; 25(2): 189-194. [Link]

25. Ghanbari B, Moghadas A. Comparing the emotional intelligence of orphanage children with ordinary children. Educational Psychology. 2011; 7(21): 7389. [Persian]. [Link]

26. Fox SE, Levitt $P$, Nelson CA. How the timing and quality of early experiences influence the development of brain architecture. Child Dev. 2010; 81(1): 28-40. [Link]

27. Rahmani J. The reliability and validity of raven's progressive matrics test among the students of azad Khorasgan University. Knowledge \& Research in Applied Psychology. 2008; (34): 61-74. [Persian]. [Link]

28. Fox NA, Rutter M. Introduction to the special section on the effects of early experience on development. Child Dev. 2010; 81(1): 23-27. [Link]

29. Jalil-Abkenar SS, Ashouri M, Afrouz GA. The effect of social behaviors training on improvement of the social skills of adolescents with intellectual disability. Archives of Rehabilitation. 2013; 14(3): 31-40. [Persian]. [Link]

30. Yousefi F, Khayer M. A study on the reliability and the validity of the matson evaluation of social skills with youngstres (MESSY) and sex differences in social skills of high school students in Shiraz, Iran. Journal of Social Sciences and Humanities of Shiraz University. 2002; 18(2): 159-170. [Persian]. [Link]

31. Müller AB, Valentini NC, Bandeira PFR. Affordances in the home environment for motor development: Validity and reliability for the use in daycare setting. Infant Behav Dev. 2017; 47: 138-145. [Link]

32. Monjardino T, Amaro J, Fonseca MJ, Rodrigues T, Santos AC, Lucas R. Early childhood as a sensitive period for the effect of growth on childhood bone mass: Evidence from Generation XXI birth cohort. Bone. 2019; 127: 287-295. [Link]

33. Perlman M, Fletcher B, Falenchuk O, Brunsek A, McMullen E, Shah PS. Child-staff ratios in early childhood education and care settings and child outcomes: a systematic review and meta-analysis. PLoS One. 2017; 12(1): e0170256. [Link]

34. Azlina W, Zulkiflee AS. A pilot study: the impact of outdoor play spaces on kindergarten children. Procedia Soc Behav Sci. 2012; 38: 275-283. [Link] 